\title{
л.в. Новоселова
}

\section{РОССИЙСКО-КИТАЙСКОЕ ИНВЕСТИЦИОННОЕ СОТРУАНИЧЕСТВО В КОНТЕКСТЕ "ПОВОРОТА РОССИИ НА ВОСТОК"}

Аннотация. В последние несколько лет российским руководством предприняты значительные усилия по улучшению инвестиционного климата в стране с иелью активизации притока иностранного капитала в Россию. Усиленно создаются территории опережающего развития с привлекательными условиями для инвесторов. Происходит совериенствование инструментария российско-китайского делового взаимодействия. Все это в значительной степени относится к дальневосточным территориям, объявленным приоритетом национальной стратегии. Первые результаты предпринятых мер уже проявились в оживлении российско-китайского инвестиционного сотрудничества.

Ключевые слова: Россия, Китай, Дальний Восток, территории опережающего развития, организационно-правовые формы сотрудничества, российско-китайские инвестиичи.

Новоселова Любовь Владимировна - доктор экономических наук, главный научный сотрудник Института Дальнего Востока РАН.

E-mail: novoselova@ifes-ras.ru

\section{L.V. Novoselova. Russian-Chinese Investment Cooperation in the Context} of «Russia's Turn Eastward»

Abstract. In the last few years the Russian government has made noticeable efforts to improve the investment climate in the country thus enhancing foreign capital inflows to Russia. Special areas of prior development with attractive conditions for investors are being rapidly established. Mechanism of Russian-Chinese business interaction is experiencing substantial improvement. All this applies to the Far East territories, being the national strategy of high priority. The first results have already revived the RussianChinese investment cooperation.

Keywords: Russia, China, Far East, areas of prior development, institutional and legal forms of cooperation, the Russian-Chinese investment. 
Novoselova Lyubov Vladimirovna - Doctor of Economics, Chief research fellow of the Institute of Far Eastern Studies.

E-mail: novoselova@ifes-ras.ru

В 2013 г. Президент РФ В. Путин объявил ускоренное развитие Сибири и Дальнего Востока абсолютным приоритетом национальной экономической стратегии. Правительству было поручено обеспечить условия для создания в регионе точек опережающего экономического роста. Вскоре после этого произошли события, обусловившие дальнейшее решительное усиление восточного вектора в российской политике. В 2014 г. разрастание вооруженного конфликта на востоке Украины, сопровождавшееся антироссийскими санкциями со стороны стран Запада и их усилиями по международной изоляции России, привело к окончательному оформлению ее «поворота на Восток».

Со своей стороны Китай обнародовал концепцию собственного продвижения на Запад посредством построения «Экономического пояса Шёлкового пути» - масштабной зоны пространственной интеграции, простирающейся от Китая до Европы и захватывающей, помимо прочего, восточные регионы России. В рамках этих инициатив Россия и Китай установили всесторонние отношения стратегического взаимодействия и партнерства, а двусторонние политические обмены достигли самого высокого уровня в истории.

Для практической реализации намеченных планов со стороны России в последние годы сделано очень много. Так, в декабре 2014 г. подписан и в марте 2015 г. вступил в силу Федеральный закон «О территориях опережающего социально-экономического развития в Российской Федерации» (ТОР). В соответствии с ним в 2015-2017 гг. первые ТОР появляются в Дальневосточном федеральном округе (ДФО), а также в моногородах со сложным социально-экономическим положением. Впоследствии они могут быть сформированы и в других регионах страны. Срок деятельности ТОР определен в 70 лет с возможностью продления, а их создание изначально ориентировано на конкретных якорных инвесторов, заключивших с государством индивидуальные соглашения на вид предполагаемой деятельности, объем инвестиций, количество создаваемых рабочих мест и т.д.

Установленный в ТОР специальный правовой режим направлен на создание привлекательных условий для инвестирования и ведения хозяйственной деятельности. Резидентам ТОР предоставляются существенные льготы: снижение ставок налогов на прибыль, имущество, землю и добычу полезных ископаемых в сочетании с налоговыми каникулами от трех до десяти лет, ускоренный возврат «экспортного» НДС. Также предусмотрены пониженные арендные ставки и ставка страховых взносов, упрощенный доступ к строительству и электросетям, облегченный порядок привлечения иностранной рабочей силы, применение беспошлинного и безналогового режима свобод- 
ной таможенной зоны и других элементов дерегулирования экономики [1]. Bсе это открывает широкие перспективы для развития деловой активности иностранных компаний.

Развитие ТОР основано на механизме государственно-частного партнерства, при этом строительство местных объектов инфраструктуры полностью финансируется из бюджетных источников [18]. Средства, выделенные из федерального бюджета на развитие ТОР в 2015-2017 гг., составляют 42 млрд руб. [6].

В 2015-2016 гг. российским правительством приняты решения о создании 15 ТОР в Приморском, Хабаровском и Камчатском краях, Амурской и Сахалинской областях, Республике Саха-Якутия, Чукотском автономном округе и Еврейской автономной области. Масштабы и уровень предоставляемых инвесторам преференций обеспечивают конкурентоспособность ТОР по сравнению с аналогичными районами льготного инвестирования в АзиатскоТихоокеанском регионе.

В июле 2015 г. был подписан Федеральный закон о предоставлении Владивостоку статуса свободного порта с льготными режимами таможенного, налогового, инвестиционного и административного регулирования. Этот закон был принят в интересах развития транспортной инфраструктуры Дальнего Востока, вовлечения его в трансграничный торговый обмен и глобальные транспортные сети, а также с целью привлечения инвестиций в создание несырьевых, ориентированных на экспорт производств.

Льготы и преференции свободного порта, в основном аналогичные правовым нормам, действующим в ТОР, распространяются на все главные порты Приморья от Зарубино до Находки, а также на международный аэропорт Владивостока (всего 15 муниципальных образований Приморского края). Таким образом, в зону действия свободного порта вошли перспективные международные транспортные коридоры «Приморье-1» и «Приморье-2». Активное использование этих коридоров способно дать ощутимую экономическую отдачу за счет переброски по железной дороге грузов из северовосточных провинций КНР в порты Приморья - с последующей отправкой морем в адрес получателей в Южном Китае, в странах АТР, Европы, а также в США.

Со вступлением в силу Федерального закона «О свободном порте Владивосток» встал вопрос о распространении этого льготного режима на другие дальневосточные порты и территории. В июле 2016 г. льготный режим начал действовать в Ванинском районе (Хабаровский край), Корсаковском районе (Сахалинская область), Певеке (Чукотский автономный округ), Петропавловске-Камчатском (Камчатский край).

Эти меры начинают приносить первые результаты. По состоянию на март 2016 г. от частных (российских и иностранных) инвесторов поступило 
110 заявок на реализацию инвестиционных проектов в ТОР на общую сумму свыше 440 млрд руб. Еще 45 заявок на 150 млрд руб. получено в зоне действия режима свободного порта [12; 17].

В ходе российского «поворота на Восток» происходит усложнение и диверсификация инструментария двустороннего российско-китайского делового взаимодействия. В 2014 г. образована Межправительственная Российско-Китайская комиссия по инвестиционному сотрудничеству. На своих ежегодных заседаниях комиссия утверждает перечень приоритетных проектов сотрудничества, контролирует осуществление этих проектов, разрабатывает предложения по улучшению инвестиционного климата двух стран.

К компетенции комиссии отнесены крупные проекты, сулящие наибольший экономический эффект. Отбор проектов и мониторинг их реализации, как и оперативное реагирование на возникающие у инвесторов проблемы, обеспечивает действующий в рамках комиссии Консультационный комитет предпринимателей. В 2014 г. комиссия курировала 32 проекта сотрудничества в сфере развития инфраструктуры, высокотехнологичной промышленности, добычи и переработки полезных ископаемых, сельском хозяйстве и др. В 2016 г. таких проектов стало 66. Общая сумма их инвестиционных амбиций около 90 млрд долл. [14].

По похожей схеме строится и российско-китайское инвестиционное сотрудничество на межрегиональном уровне. Так, в 2013 г. начал работу Круглый стол руководителей регионов Приволжского федерального округа и провинций верхнего и среднего течения реки Янцзы, преобразованный в 2016 г. в Совет по российско-китайскому межрегиональному сотрудничеству в формате «Волга-Янцзы». По состоянию на июль 2016 г. в рамках Совета, действующего на паритетной ежегодной основе, прорабатывалось 69 инвестиционных проектов, из которых 27 либо реализованы, либо находились в стадии реализации [3].

В 2015 г. создан Совет сотрудничества между регионами российского Дальнего Востока и Северо-Востока КНР, годом позже он преобразован в российско-китайскую смешанную Межправительственную комиссию по развитию Дальнего Востока России и Северо-Востока КНР. Задача комиссии - способствовать повышению темпов реализации проектов двустороннего сотрудничества на Дальнем Востоке.

Одновременно получают все большее распространение соглашения о сотрудничестве между отдельными российскими регионами и провинциями КНР. Только в 2014 г. такие соглашения подписаны между Республикой Башкортостан и провинцией Цзянси, Пермским краем и провинцией Цзянси, Республикой Татарстан и провинцией Хунань.

Для обеспечения этих соглашений формируется соответствующая финансовая инфраструктура. В 2012 г. Российский фонд прямых инвестиций 
(РФПИ) на паях с Китайской инвестиционной корпорацией (СIC) учредили Российско-китайский инвестиционный фонд (РКИФ), внеся в его капитал по 1 млрд долл. и рассчитывая привлечь еще 2 млрд долл. от ведущих китайских инвесторов ${ }^{1}$.

В 2016 г. профинансированные и одобренные РКИФ сделки достигли 4 млрд долл. Приоритет в работе фонда отдается таким направлениям, как инфраструктура и логистика, агропромышленный комплекс, глубокая переработка природных ресурсов, высокотехнологичная обрабатывающая промышленность, сфера услуг, включая туризм и путешествия. Более $70 \%$ средств РКИФ инвестируется в России, до $30 \%$ - в КНР.

Одним из таких проектов стало создание РКИФ в ноябре 2016 г. совместно с китайской компанией «Tus-Holdings» (управляющая компания крупнейшего технопарка в мире) Российско-китайского венчурного фонда (РКВФ). Капитал фонда (100 млн долл.) в перспективе может быть пополнен, а его участниками могут стать и другие российские и китайские институциональные инвесторы. РКВФ планирует инвестировать в высокотехнологичные российские компании с потенциалом развития на рынке КНР [13].

В апреле 2016 г. в рамках договоренности между Минвостокразвития России и Госкомитетом по развитию и реформам КНР о совместном финансировании сельскохозяйственного производства на Дальнем Востоке создан Российско-китайский фонд агропромышленного развития (РКФАР). Учредителями фонда стали российский Фонд развития Дальнего Востока и Азиатско-Тихоокеанский продовольственный фонд (КНР).

Предусмотрено, что земля под совместные сельскохозяйственные проекты выделяется исключительно российским участникам при обязательном использовании ими современных аграрных технологий. Не менее $80 \%$ создаваемых рабочих мест должны занимать россияне. Российские поставщики товаров и услуг пользуются приоритетом при реализации проектов фонда.

Выступая своего рода катализатором инвестиционного процесса, РКФАР из собственных средств финансирует $10 \%$ стоимости проекта, еще $10 \%$ предоставляют его инициаторы, оставшиеся $80 \%$ привлекаются в кредит от российских или китайских банков-партнеров [10]. Участниками Соглашения о взаимодействии в рамках РКФАР являются крупнейшие банки, включая

1. РФПИ основан в 2011 г. с капитализачией в размере 10 млрд долл., выделяемых российским правительством для осуществления доходных инвестиций в капитал компаний на принщипах соинвестирования. Управляющая компания фонда является 100\% дочерним обществом Внешэкономбанка. СІС - Китайский суверенный фонд благосостояния, государственная компания, образованная в 2007 г. в целях диверсификации золотовалютных резервов Китая и обеспечения более высокой доходности инвестииий. 
Сельскохозяйственный банк Китая, Строительный банк Китая и Торговопромышленный банк Китая.

Первые контракты подписаны РКФАР в сентябре 2016 г. Партнерами фонда стали известные дальневосточные компании «Ратимир» (строительство в ТОР Приморского края свиноводческого комплекса стоимостью в 15 млрд руб.) и «Амур Агро Холдинг» (строительство в Амурской области заводов по глубокой переработке пшеницы и сои - 2,9 млрд руб.) [6].

Политические инициативы и организационные усилия последних лет, подкрепленные соответствующей активностью национальных компаний, привели к очевидному оживлению российско-китайского инвестиционного взаимодействия. С каждым годом появляется все больше новых совместных проектов, укрепляющих двустороннее сотрудничество.

Как свидетельствует таблица 1, в 2015 г. китайские инвестиции в Россию составили 3 млрд долл., увеличившись в 4,7 раза по сравнению с предыдущим годом. Накопленные инвестиции Китая достигли 14,6 млрд долл., позволив ему подняться на четвертую позицию в списке иностранных инвесторов в российскую экономику [25]. Доля России в экспорте китайского капитала в 2015 г. составила $2,4 \%$ против $0,5 \%$ годом ранее.

ИНВЕСТИЦИОННОЕ СОТРУАНИЧЕСТВО РОССИИ И КИТАЯ

Таблица 1

(МАн АОМм.)

\begin{tabular}{|l|c|c|c|c|c|c|c|}
\hline & 2010 & 2011 & 2012 & 2013 & 2014 & 2015 & $\begin{array}{l}\text { Накопленные } \\
\text { инвестиции } \\
\text { на конец 2015 2. }\end{array}$ \\
\hline $\begin{array}{l}\text { Прямые инвести- } \\
\text { ции России в Китай }\end{array}$ & 35,0 & 31,0 & 29,9 & 22,1 & 40,9 & 13,1 & 946,9 \\
\hline $\begin{array}{l}\text { Прямые инвести- } \\
\text { ции Китая в Россию }\end{array}$ & 567,7 & 715,8 & 784,6 & 1022,2 & 633,6 & 2960,9 & 14566,7 \\
\hline
\end{tabular}

Составлено по: [19, табл. 6-14, 6-19; 20, табл. 6-13, 6-18; 21, табл. 11-14, 11-19; 22, табл. 11-14, 11-19].

Эти успехи, однако, выглядят не столь впечатляюще на фоне глобальной инвестиционной экспансии Китая. Ведь современный Китай - это один из крупнейших международных инвесторов. В 2016 г., по данным Министерства коммерции КНР, прямые китайские инвестиции за рубежом превысили 170 млрд долл., а темпы их годового прироста составили 44,1\% [7]. Все это говорит о пока еще скромных размерах российско-китайского инвестиционного сотрудничества. В то же время у этого сотрудничества поистине огромный потенциал. Велики и возможности наращивания инвестиционного присутствия Китая в России. 
Уже сегодня эти возможности находят воплощение на Дальнем Востоке России. В 2016 г. в ДФО сумма подписанных соглашений о реализации инвестиционных проектов с негосударственными вкладчиками капитала достигла 1,3 трлн руб. При этом, согласно Минвостокразвития России, $22 \%$ общей суммы капиталовложений (или 4,8 млрд долл.) приходится на зарубежных инвесторов, среди которых уверенно лидируют компании КНР, обеспечивающие почти $2 / 3$ притока иностранных инвестиций. Если сегодня на Дальнем Востоке реализуется в общей сложности 23 проекта с суммой инвестиций из КНР в 3 млрд долл., то в 2018 г. этот показатель предполагается увеличить до 16 млрд долл.

Китайские инвесторы развивают бизнес в дальневосточных ТОР, где в 2016 г. на их долю пришлось $25 \%$ негосударственных инвестиций. Например, в ТОР «Михайловское» (Приморский край) они планируют построить животноводческий комплекс, а также предприятия по очистке зерна, переработке сои и производству комбикормов. В ТОР «Хабаровск» компания «Baoli Bitumina» намерена построить завод по производству современных битумных материалов. В ТОР «Кангалассы» (Якутия) китайские резиденты инвестируют в строительство двух предприятий по производству стройматериалов [15].

В отличие от этого капиталовложения российских компаний в КНР, характеризовавшиеся и ранее небольшими объемами, не показывают тенденции к росту. По состоянию на 2015 г. накопленные размеры этих инвестиций не достигали и 1 млрд долл., а их доля в общем притоке иностранного предпринимательского капитала в Китай осталась на уровне статистической погрешности (в 2015 г. - 0,01\%).

Низкие показатели вложений российского капитала в КНР, судя по всему, связаны и с тем, что в ряде случаев финансовые ресурсы из России поступают в Китай не напрямую, а через Гонконг или другие юрисдикции с льготным налогообложением. Однако официальные данные о вывозе российского капитала в эти юрисдикции также не позволяют говорить о скольконибудь существенной инвестиционной активности России в Китае. В итоге с течением времени российско-китайское инвестиционное сотрудничество превратилось, по сути, в «улицу с односторонним движением» [8].

В соответствии с опросом, проведенным консалтинговой компанией «IPT Group» среди компаний КНР, работающих в России, наиболее важными факторами ее привлекательности для китайских инвесторов являются наличие богатых и разнообразных природных ресурсов (71\% респондентов), степень развития инфраструктуры (43\%) и доступ к высоким технологиям (43\%) [12].

Наблюдаемый сегодня рост интереса китайской стороны к современным технологиям соответствует национальной экономической стратегии Китая c ее ставкой на инновации. Конкурируя с американскими и азиатскими компаниями, КНР стремительно сокращает отставание от них в целом ряде высоко- 
технологичных производств. По различным оценкам, за первое полугодие 2016 г. доля китайских смартфонов на российском рынке составила от 30 до $56 \%$. В этих условиях производители технологических китайских брендов не только открывают дочерние компании в России, но и рассматривают возможность размещения здесь своего производства.

Китайских партнеров интересуют и российские достижения в таких областях, как медицинские и биотехнологии, микроэлектроника, светодиоды, робототехника, телекоммуникации, технологические решения в финансовом секторе и в области переработки отходов и т.д. В конце 2016 г. достигнута договоренность о сотрудничестве в области информационных, авиакосмических, «зеленых» технологий, а также в сфере систем спутниковой навигации [2].

Не менее важным с точки зрения активизации российско-китайского инвестиционного взаимодействия является и повышение жизненного уровня населения КНР с возрастанием интереса китайцев к здоровому образу жизни, включая потребление экологически чистых продуктов питания. В последнее время значительно увеличился экспорт российских овощей, фруктов и мясных продуктов в Китай. При активной государственной поддержке сотрудничество в сельскохозяйственном секторе все более переходит от чистой торговли к модели объединения инвестиций с технологическим сотрудничеством. Отсюда - рост китайских инвестиций в сельское хозяйство России.

Данное направление выглядит весьма многообещающим, ведь Россия сегодня является одним из ведущих мировых экспортеров сельскохозяйственной продукции и продуктов питания. К тому же перспективные с точки зрения агробизнеса земли Сибири и Дальнего Востока в настоящее время практически простаивают.

На территории Омской области, например, китайскими инвесторами создается агропромышленный кластер, продукция которого предназначена для экспорта в Китай. В Забайкальском крае китайские инвестиции (24 млрд руб.) будут направлены на развитие сельского хозяйства на неиспользуемых пахотных землях и пастбищах. В 2016 г. крупнейший в Китае производитель продуктов «China National Cereals, Oils and Foodstuffs Corporation» (COFCO) объявил об открытии филиала на Дальнем Востоке России. СОFСО планирует выращивать и перерабатывать в Приморье соевые бобы, а также экспортировать отсюда мясо и воду $[16 ; 24]$.

Особенностью российско-китайского инвестиционного сотрудничества является также усиление деловой активности КНР в сфере недвижимости, международного туризма и индустрии развлечений. В последние годы поток китайских туристов в Россию постоянно увеличивается. К тому же создание объектов недвижимости является одним из важных направлений китайского экспорта капитала: зарубежные инвестиции КНР в недвижимость в 2015 г. 
составили 8,5 млрд долл. против 1 млрд долл. в 2009 г. Сегодня к крупным городам Австралии, США, Великобритании в списке приоритетов китайских инвесторов добавляются и восточные территории России.

Среди крупнейших проектов такого рода следует отметить комплексную застройку жилых микрорайонов в Улан-Удэ и Забайкальске, участие корпорации «Говэй Цайфу» в строительстве игорной зоны «Приморье» (общая сумма инвестиций $-2,7$ млрд долл.). Также следует упомянуть обнародованный в конце 2016 г. мегапроект по созданию современного туристического кластера в Байкальском регионе совместными усилиями дочерних структур Китайской международной инвестиционно-трастовой корпорации (CITIC), ПАО «Иркутскэнерго» и принадлежащей О. Дерипаске компании «ГОСТ Отель Менеджмент» (11 млрд долл.) [4]. В целом удельный вес туризма, индустрии развлечений и сектора высоких технологий в общем потоке китайских инвестиций в Россию в 2015-2016 гг. составил 46\% против $17,4 \%$ в 2005-2014 гг. [2].

В настоящее время доступ России к ресурсам международного финансового рынка ограничен, проблема ликвидности российского бизнеса стоит весьма остро. Соответственно, активизируется деятельность китайских инвесторов, связанная с приобретением заметных долей в акционерном капитале крупных российских корпораций. Многие из этих компаний работают в традиционно интересующих КНР сырьевых отраслях.

В 2015-2016 гг. крупнейшими сделками такого рода стали:

- покупка компанией CNPC и Фондом Шёлкового пути, соответственно, 20 и 9,9\% акций в ПАО «Ямал-СПГ», реализующем крупный проект по добыче, сжижению и поставке природного газа (сумма сделок оценивается свыше 1 млрд долл.);

- покупка Китайской инвестиционной корпорацией $12,5 \%$ акций «Уралкалия» (2 млрд долл.) и 5,4\% акций Московской биржи (100 млн долл.);

- приобретение $10 \%$ акций ПАО «Сибур Холдинг» (1,3 млрд долл.) корпорацией «Sinopec Group» и еще 10\% - Фондом Шёлкового пути;

- приобретение Строительным банком Китая $2 \%$ акций банка ВТБ (100 млн долл.);

- приобретение инвестиционным консорциумом «Highland Fund» у ПАО «ГМК «Норильский никель» 13,3\% в проекте «Быстринский ГОК» [16].

Приобретая активы, компании КНР получают доступ к необходимым им природным ресурсам и технологиям, а также дополнительные возможности влияния на развитие ряда крупнейших российских предприятий и даже отраслей. Что касается российской стороны, то хотя она и не расширяет свои производственные мощности, однако ослабляет напряженность с ликвидностью и рассчитывает на укрепление связей с ведущими финансовыми институтами Китая. 
Однако, как показывает практика, далеко не всегда этим надеждам суждено сбыться. В условиях сохранения антироссийских санкций и нарастания связанных с Россией страновых рисков китайские банки проявляют большую осторожность и сдержанность при обслуживании и финансировании сделок с участием российских компаний. В этих условиях кредитные линии российским банкам все чаще предоставляет не «большая четверка» государственных коммерческих банков КНР, а так называемые политические банки - Банк развития Китая и Экспортно-импортный банк, ресурсы которых не столь велики.

В целом задержки и срывы финансирования либо его несогласованное сокращение являются, пожалуй, главной претензией российского бизнеса в его взаимоотношениях с партнерами из КНР. Наиболее ярким, хотя и далеко не единственным, примером такого рода является отказ китайской стороны от участия в финансировании строительства газопровода «Сила Сибири», несмотря на попытки «Газпрома» получить на эти цели аванс в 25 млрд долл. В результате в 2016 г. инвестиционная программа российского газового монополиста была сокращена, и вместо ранее планировавшихся 800 км газопровода в течение года было построено лишь 400 км [9].

Список неудовлетворенностей китайской стороны в сотрудничестве с Россией значительно шире.

Таблица 2

\section{ОСНОВНЫЕ ПРЕПЯТСТВИЯ}

ААЯ ОСУЩЕСТВАЕНИЯ КИТАЙСКИХ ИНВЕСТИЦИЙ В РОССИЮ

\begin{tabular}{|l|c|}
\hline \multicolumn{1}{|c|}{ Содержание } & $\begin{array}{c}\text { Удельный вес } \\
\text { респондентов (\%) }\end{array}$ \\
\hline Нестабильная макроэкономическая ситуация & 57 \\
\hline Проблемы правоприменения & 43 \\
\hline Падение покупательной способности населения & 29 \\
\hline Коррупция & 14 \\
\hline Санкции и осложнение отношений с Западом & 14 \\
\hline Сложные процедуры регистрации собственности, торговых марок & 14 \\
\hline
\end{tabular}

Составлено на основании опроса участников рынка консалтинговой компанией «IPT Group» в 2016 г. См.: [12].

Как свидетельствуют данные таблицы 2, основным препятствием для осуществления китайских инвестиций в Россию, по мнению самих участников рынка, является нестабильная макроэкономическая ситуация в нашей стране. В этой связи специалисты Исследовательского центра Фуданьского университета подчеркивают, что российская экономика чрезмерно зависит от колебания мировых цен на энергоносители, а экономической политике России не хватает последовательности и определенности [23]. 
Большие вопросы у китайских партнеров вызывает и российская практика правоприменения. По их мнению, эффективность работы государственных структур в России падает, надзорные органы не в полной мере выполняют свои функции. Исполнение законодательных актов, включая международные соглашения, носит избирательный характер. Ситуация усугубляется широким распространением правовых коллизий, а также отсутствием ясного разграничения полномочий между федеральными и местными органами власти. В результате непомерно возрастает значение административного ресурса, ширятся масштабы коррупции.

С точки зрения китайских инвесторов, на инвестиционную привлекательность России негативно влияют и такие факторы, как высокие административные барьеры выхода на рынок, а также несовершенство системы технического регулирования. В то время как китайские компании у себя дома и за рубежом давно ориентируются на международные стандарты качества и сертификации, в России до сих пор применяются стандарты ГОСТа, нуждающиеся в обновлении в соответствии с современными международными практиками. Все это препятствует реализации совместных российско-китайских проектов сотрудничества [23].

Не удивительно, что основными субъектами экономических отношений в этих условиях выступают крупные государственные компании, обладающие серьезным административным и политическим ресурсом и опирающиеся, при необходимости, на бюджетное финансирование. Это может иметь известный положительный эффект, особенно на начальном этапе сотрудничества, позволяя придать ему сильный стартовый импульс. Очевидные недостатки такой модели сотрудничества связаны с бюрократизацией экономических отношений, низкой мобильностью принятия решений, слабым реагированием на сигналы рынка и, как следствие, невысокой экономической эффективностью.

Между тем в последние 10-15 лет развитие российской экономики идет по пути прогрессирующего огосударствления и усиления монополистических тенденций. По данным Федеральной антимонопольной службы, вклад государства (включая госкомпании, унитарные предприятия и т.д.) в ВВП России вырос с $35 \%$ в 2005 г. до $70 \%$ - в 2015 г. [5].

В отличие от России, в Китае в рамках последовательной рыночной трансформации из года в год наблюдается все большее сокращение масштабов госсектора и его доли в экономике. Число государственных предприятий уменьшается. А удельный вес негосударственных инвестиций увеличивается (с 35\% валовых капиталовложений в 2006 г. до $64 \%$ - в 2015 г.). Поощряется и экспорт капитала частными китайскими компаниями. В 2015 г. их доля в общем объеме зарубежных инвестиций КНР достигла $65 \%$, а в сделках по слиянию и поглощению - даже $76 \%$. Развитие России и Китая, таким 
образом, находится в своеобразной противофазе, что вряд ли может способствовать их плодотворному экономическому и инвестиционному взаимодействию.

Если мы действительно хотим использовать высокую энергетику развития Китая в интересах подъема собственной экономики, то нашей стране следует озаботиться укреплением своих позиций в качестве полноценного делового партнера КНР, а не просто участника оживленного политического диалога на высоком уровне. В перспективе для поддержания нынешней активизации инвестиционных потоков необходимо модернизировать и диверсифицировать российскую экономику, повысить степень ее коммерциализации и инновационный потенциал. При этом, сокращая уровень огосударствления и монополизации, стимулируя развитие конкурентной рыночной среды, важно развивать частный российский бизнес и поощрять его включение в международный экономический обмен. В противном случае Россия рискует остаться объектом одностороннего приложения китайских инвестиций в отраслях и регионах, представляющих стратегический интерес для нашего восточного соседа.

\section{Библиография}

1. Акционерное общество «Корпорация развития Дальнего Востока». Официальный сайт // URL: http://erdc.ru/ (Дата обращения: 06.05.2017.)

2. Бухарова О. Особенности перевода: Российский и китайский бизнес нашли общий язык // Российская газета. 2016. 25 мая. URL: https://rg.ru/2016/05/25/kitajcy-sochli-rossiiuprivlekatelnoj-dlia-investicij.html (Дата обращения: 20.04.2017.)

3. В Ульяновске состоялось первое заседание Совета по межрегиональному сотрудничеству в формате «Волга-Янцзы» // Официальный сайт Полномочного представителя Президента Российской Федерации в Приволжском административном округе. URL: http://pfo.gov.ru/ press/events/100350/ (Дата обращения: 05.05.2017.)

4. Инвесторы Китая построят в Приморье игорную зону // Newsland. 2016. 13 декабря. URL: https://newsland.com/user/epochtimes/content/investory-kitaia-postroiat-v-primore-igornuiuzonu/5597036 (Дата обращения: 21.04.2017.)

5. Мереминская Е. Государева доля // Ведомости. 2016. 29 сентября.

6. Министерство Российской Федерации по развитию Дальнего Востока. Официальный сайт // URL: http://www.minvostokrazvitia.ru/press-center/news_minvostok/?ELEMENT_ID=2839 (Дата обращения: 06.05.2017.)

7. Объем прямых китайских инвестиций за рубеж в 2016 г. вырос на 44,1\% // Regnum. Информационное агентство. 2017. 17 января. URL: https://regnum.ru/news/economy/2227601.html (Дата обращения: 23.04.2017.)

8. Основные итоги инвестиционного сотрудничества России и Китая // Министерство экономического развития Российской Федерации. Портал внешнеэкономической информации. URL: http://www.ved.gov.ru/exportcountries/cn/cn_ru_relations/cn_rus_projects/ (Дата обращения: 24.04.2017.) 
9. Подобедова Л. «Газпром» изменил планы стройки газопровода в Китай // РБК. 2017. 19 мая. URL: http://www.rbc.ru/business/19/05/2016/573d779f9a79474b61282000 (Дата обращения: 21.04.2017.)

10. Подписано акционерное соглашение о создании российско-китайского фонда агропромышленного развития на Дальнем Востоке (РКФАР) // Фонд развития Дальнего Востока. Официальный сайт. 2016. 26 апреля. URL: http://fondvostok.ru/press-tsentr/publikatsii/podpisanoaktsionernoe-soglashenie-o-sozdanii-rossiysko-kitayskogo-fonda-agropromyshlennogo-razvitiya/ (Дата обращения: 05.05.2017.)

11. Правительство Российской Федерации. Официальный сайт // URL: http://government.ru/info/27709/\# (Дата обращения: 22.03.2017.)

12. $57 \%$ китайских компаний планируют увеличить инвестиции в Россию // Invest Raiting. 2016. 12 августа. URL: http://www.invest-rating.ru/russia-china/?id=5056 (Дата обращения: 06.05.2017.)

13. Россия и Китай создают совместный венчурный фонд // Русская весна. 2016. 7 ноября. URL: http://rusvesna.su/economy/1478505784 (Дата обращения: 05.05.2017.)

14. Состоялось третье заседание Межправительственной Российско-Китайской комиссии по инвестиционному сотрудничеству // Министерство экономического развития Российской Федерации. Официальный сайт. URL: http://economy.gov.ru/minec/about/structure/depInvest/ 2016270604 (Дата обращения: 05.05.2017.)

15. Сотрудничество ДФО и Северо-Востока Китая - итоги 2015 // East Russia. 2016. 4 января. URL: http://www.eastrussia.ru/news/sotrudnichestvo-dfo-i-severo-vostoka-kitaya-itogi2015/ (Дата обращения: 06.05.2017.)

16. Сферы российско-китайских инвестиций // East Russia. URL: http://www.investrating.ru/russia-china-spheres/ (Дата обращения: 06.05.2017.)

17. Территории опережающего развития: 12 особых зон в ДФО // ТАСС. 2015. 27 августа. Обновлено: 2016. 11 июля. URL: http://tass.ru/info/2215388http://tass.ru/info/2215388 (Дата обращения: 06.05.2017.)

18. ТОСЭР // Фонд развития Дальнего Востока. Официальный сайт. URL: http:// fondvostok.ru/toser/ (Дата обращения: 06.05.2017.)

19. Чжунго тунцзи няньцзянь 2.2011 г. Пекин: Чжунго тунцзи чубаньшэ, 2011.

20. Чжунго тунцзи няньцзянь. 2013 г. Пекин: Чжунго тунцзи чубаньшэ, 2013.

21. Чжунго тунцзи няньцзянь. 2015 г. Пекин: Чжунго тунцзи чубаньшэ, 2015.

22. Чжунго тунцзи няньцзянь. 2016 г. Пекин: Чжунго тунцзи чубаньшэ, 2016.

23. Шишкина Н.И. Основные области и направления российско-китайских экономических отношений // Центр Сулакшина (Центр научной политической мысли и идеологии). URL: http://rusrand.ru/analytics/osnovnye-oblasti-i-napravleniya-rossiysko-kitayskih-ekonomicheskihotnosheniy (Дата обращения: 22.04.2017.)

24. COFСО открывает филиал на Дальнем Востоке РФ // Cina Pro: Деловой журнал про Китай. 2016. 15 декабря. URL: http://www.chinapro.ru/rubrics/1/15010/ (Дата обращения: 06.05.2017.)

25. Regular Press Conference of Ministry of Commerce (December 29, 2016) // Ministry of Commerce of the PRC. URL: http://english.mofcom.gov.cn/article/newsrelease/press/201701/ 20170102496126.shtml (Дата обращения: 25.04.2017.)

2. Китайский статистический ежегодник. 


\section{References}

57\% kitajskih kompanij planirujut uvelichit' investicii v Rossiju // Invest Raiting. 2016. 12 avgusta. URL: http://www.invest-rating.ru/russia-china/?id=5056 (Data obrashhenija: 06.05.2017.)

Akcionernoe obshhestvo «Korporacija razvitija Dal'nego Vostoka». Oficial'nyj sajt // URL: http://erdc.ru/ (Data obrashhenija: 06.05.2017.)

Buharova O. Osobennosti perevoda: Rossijskij i kitajskij biznes nashli obshhij jazyk // Rossijskaja gazeta. 2016. 25 maja. URL: https://rg.ru/2016/05/25/kitajcy-sochli-rossiiu-privlekatelnoj-dliainvesticij.html (Data obrashhenija: 20.04.2017.)

Chzhungo tunczi njan'czjan' . 2011 g. Pekin: Chzhungo tunczi chuban'shje, 2011.

Chzhungo tunczi njan'czjan'. 2013 g. Pekin: Chzhungo tunczi chuban'shje, 2013.

Chzhungo tunczi njan'czjan'. 2015 g. Pekin: Chzhungo tunczi chuban'shje, 2015.

Chzhungo tunczi njan'czjan'. 2016 g. Pekin: Chzhungo tunczi chuban'shje, 2016.

COFCO otkryvaet filial na Dal'nem Vostoke RF // Cina Pro: Delovoj zhurnal pro Kitaj. 2016. 15 dekabrja. URL: http://www.chinapro.ru/rubrics/1/15010/ (Data obrashhenija: 06.05.2017.)

Investory Kitaja postrojat v Primor'e igornuju zonu // Newsland. 2016. 13 dekabrja. URL: https://newsland.com/user/epochtimes/content/investory-kitaia-postroiat-v-primore-igornuiuzonu/5597036 (Data obrashhenija: 21.04.2017.)

Mereminskaja E. Gosudareva dolja // Vedomosti. 2016. 29 sentjabrja.

Ministerstvo Rossijskoj Federacii po razvitiju Dal'nego Vostoka. Oficial'nyj sajt // URL: http:// www.minvostokrazvitia.ru/press-center/news_minvostok/?ELEMENT_ID=2839 (Data obrashhenija: 06.05.2017.)

Ob'em prjamyh kitajskih investicij za rubezh v 2016 g. vyros na 44,1\% // Regnum. Informacionnoe agentstvo. 2017. 17 janvarja. URL: https://regnum.ru/news/economy/2227601.html (Data obrashhenija: 23.04.2017.)

Osnovnye itogi investicionnogo sotrudnichestva Rossii i Kitaja // Ministerstvo jekonomicheskogo razvitija Rossijskoj Federacii. Portal vneshnejekonomicheskoj informacii. URL: http:// www.ved.gov.ru/exportcountries/cn/cn_ru_relations/cn_rus_projects/ (Data obrashhenija: 24.04.2017.)

Podobedova L. «Gazprom» izmenil plany strojki gazoprovoda v Kitaj // RBK. 2017. 19 maja. URL: http://www.rbc.ru/business/19/05/2016/573d779f9a79474b61282000 (Data obrashhenija: 21.04.2017.)

Podpisano akcionernoe soglashenie o sozdanii rossijsko-kitajskogo fonda agropromyshlennogo razvitija na Dal'nem Vostoke (RKFAR) // Fond razvitija Dal'nego Vostoka. Oficial'nyj sajt. 2016. 26 aprelja. URL: http://fondvostok.ru/press-tsentr/publikatsii/podpisano-aktsionernoe-soglashenie-osozdanii-rossiysko-kitayskogo-fonda-agropromyshlennogo-razvitiya/ (Data obrashhenija: 05.05.2017.)

Pravitel'stvo Rossijskoj Federacii. Oficial'nyj sajt // URL: http://government.ru/info/27709/\# (Data obrashhenija: 22.03.2017.)

Regular Press Conference of Ministry of Commerce (December 29, 2016) // Ministry of Commerce of the PRC. URL: http://english.mofcom.gov.cn/article/newsrelease/press/201701/ 20170102496126.shtml (Data obrashhenija: 25.04.2017.)

Rossija i Kitaj sozdajut sovmestnyj venchurnyj fond // Russkaja vesna. 2016. 7 nojabrja. URL: http://rusvesna.su/economy/1478505784 (Data obrashhenija: 05.05.2017.)

Sfery rossijsko-kitajskih investicij // East Russia. URL: http://www.invest-rating.ru/russiachina-spheres/ (Data obrashhenija: 06.05.2017.)

Shishkina N.I. Osnovnye oblasti i napravlenija rossijsko-kitajskih jekonomicheskih otnoshenij // Centr Sulakshina (Centr nauchnoj politicheskoj mysli i ideologii). URL: http://rusrand.ru/ analytics/osnovnye-oblasti-i-napravleniya-rossiysko-kitayskih-ekonomicheskih-otnosheniy (Data obrashhenija: 22.04.2017.) 
Sostojalos' tret'e zasedanie Mezhpravitel'stvennoj Rossijsko-Kitajskoj komissii po investicionnomu sotrudnichestvu // Ministerstvo jekonomicheskogo razvitija Rossijskoj Federacii. Oficial'nyj sajt. URL: http://economy.gov.ru/minec/about/structure/depInvest/2016270604 (Data obrashhenija: 05.05.2017.)

Sotrudnichestvo DFO i Severo-Vostoka Kitaja - itogi 2015 // East Russia. 2016. 4 janvarja. URL: http://www.eastrussia.ru/news/sotrudnichestvo-dfo-i-severo-vostoka-kitaya-itogi-2015/ (Data obrashhenija: 06.05.2017.)

Territorii operezhajushhego razvitija: 12 osobyh zon v DFO // TASS. 2015. 27 avgusta. Obnovleno: 2016. 11 ijulja. URL: http://tass.ru/info/2215388http://tass.ru/info/2215388 (Data obrashhenija: 06.05.2017.)

TOSJeR // Fond razvitija Dal'nego Vostoka. Oficial'nyj sajt. URL: http://fondvostok.ru/toser/ (Data obrashhenija: 06.05.2017.)

V Ul'janovske sostojalos' pervoe zasedanie Soveta po mezhregional'nomu sotrudnichestvu v formate "Volga-Janczy» // Oficial'nyj sajt Polnomochnogo predstavitelja Prezidenta Rossijskoj Federacii v Privolzhskom administrativnom okruge. URL: http://pfo.gov.ru/press/events/100350/ (Data obrashhenija: 05.05.2017.) 